\title{
Research Fellowships and Grants
}

\section{Royal Society Awards}

$\mathrm{T}$ HE Council of the Royal Society decided in the spring of this year to found an E. Alan Johnston and Lawrence research fellowship in medicine by means of funds available to the Society by bequests under these two names. The value of the stipend is $£ 700$ per annum, plus superannuation allowance. Seventeen candidates applied for the fellowship and of these, four were selected for special consideration. Council would gladly have appointed any one of them to a fellowship had four fellowships been available. The reception of the fellowship is a strong indication that candidates of high merit are available for full-time research posts in medicine. Council finally selected Dr. John McMichael, of Edinburgh, to work at the Edinburgh Royal Infirmary on the pathology of heart failure. From 1934 to 1936 he has been a lecturer in human physiology at Edinburgh. He has been offered special facilities for his work at the Edinburgh Royal Infirmary.

The Council of the Royal Society has also approved plans for medical research on malaria and on nutrition in India, involving a total expenditure of more than $£ 8,000$ in the next five years. Colonel Sinton has been appointed to investigate certain aspects of malaria at the Horton Centre. Another series of investigations on malaria, in conjunction with the London School of Hygiene and Tropical Medicine, provides for a study of mosquitos in the tropics, and Dr. C. Wilson has been offered a research appointment to enable a survey of nutritional conditions in India to be undertaken.

\section{LeVerhulMe Fellowships and Grants}

Awards of Leverhulme fellowships and grants in aid for research for 1936 have been made to the following, among others, the subject of research being indicated in brackets: Dr. Agnes Arber (studies in the principles of angiospermous morphology and in the history of botany); S. J. Duly, head of the Department for the Sçientific Study of Commercial Products, City of London College (carriage of goods by sea); Dr. F. Fairbrother, senior lecturer in chemistry, University of Manchester (the study of electrolytic dissociation processes and the mechanisms of chemical reactions by the use of induced radioactivity) ; C. P. Fitzgerald (sociology of the non-Chinese tribes of Yunnan, S.W. China); S. D. Garrett, formerly assistant plant pathologist, Waite Agricultural Research Institute, University of Adelaide, South Australia (biological antagonism of the soil microflora towards root disease fungi or crop plants - renewal of present fellowship); Dr. J. de Graaff Hunter, lately director of the Survey of India (planning and execution of geodetic triangulation of great extent); Mrs. K. Lonsdale, research worker, Royal Institution (relation between structure and physical properties of organic molecules-renewal of present fellowship); E. P. Mumford, lately director of the Pacific Entomological Survey, Honolulu (terrestrial and freshwater biota of the Marquesas Islands-renewal of present fellowship); F. R. Perry, member of Research Department, Metropolitan-Vickers Electrical Co., Ltd.,
Manchester (the study of overvoltages due to lightning on transmission lines-renewal of present fellowship); Dr. A. L. Reimann, research physicist, General Electric Company, Limited, Wembley, Middlesex (electronic conduction phenomena in solid insulators and semi-conductors); Dr. R. H. Thouless, head of the Department of Psychology, University of Glasgow (research in visual perception); Dr. W. E. Williams, lecturer in physics, King's College, London (determination of the vacuum wave-lengths and the structures of spectral lines by means of his reflection échelon).

Grants in aid of research have been made to the following: Prof. A. E. Boycott, late Graham professor of pathology, University of London (ecology and genetics of British non-marine Mollusca); Prof. H. J. Fleure, professor of geography, University of Manchester (physical (racial) characteristics of the peoples of Wales); Prof. J. W. Heslop Harrison, professor of botany, Armstrong College, Newcastleon-Tyne (researches on evolution and heredityrenewal of present grant) ; T. N. Hoblyn, statistician, East Malling Research Station, Kent (technical problems in the layout and conduct of horticultural field experiments under tropical and sub-tropical conditions) ; Dr. W. H. Pearsall, reader in botany, University of Leeds (growth of Algæ); Dr. O. W. Richards, lecturer in entomology, Imperial College of Science and Technology, London (habits of South American bees and wasps); Prof. C. W. Valentine, professor of education, University of Birmingham (psychology of early childhood). A Leverhulme travelling fellowship has been awarded to $\mathbf{M r}$. A. Ruscoe Clarke on the nomination of the Medical Research Council.

Particulars of these awards can be obtained from the Secretary, Leverhulme Research Fellowships, Union House, St. Martins-le-Grand, London, E.C.1.

\section{Beit Memorial Fellowships}

The trustees of the Beit Memorial fellowships for medical research have made the following awards, the subject and place of research being given after the name of each now fellow : Fourth Year Fellowships (£500 a year): Dr. E. S. Horning, to continue his research on the cancer-producing effects of œstrogenic compounds, and on the possibility of producing tumours in vitro (Imperial Cancer Research Fund, Queen Square, London); Dr. W. J. Dann, to continue his work on the vitamin $\mathrm{B}_{2}$ complex in reference to the treatment of pellagra (Duke University School of Medicine, North Carolina, U.S.A.). Junior Fellowships ( $\$ 400$ a year): Dr. I. Berenblum, to study the mechanism of skin irritation by chemical substances in reference to their action as exciting or preventing the development of cancer (Dunn School of Pathology, University of Oxford) ; D. D. Woods, to study the metabolism of the anaerobic bacteria, and the phenomenon of adaptation in bacteria (Dunn Institute of Biochemistry, University of Cambridge) ; Dr. A. Neuberger, to study the carbohydrate group in proteins and its possible relationship to their antigenic properties in bacterial immunity (Department 
of Pathological Chemistry, University College Hospital Medical School, London); C. W. Bellerby, to investigate the control of the reproductive cycle by the anterior lobe of the pituitary (Department of Social Biology, University of London); Dr. T. W. Birch, to attempt to identify the component parts of the vitamin $\mathrm{B}_{2}$ complex (Nutritional Laboratory, Cambridge); Lilian M. Pickford, to study the part played by the posterior pituitary gland in the control of water excretion by the kidneys (Pharmacological Laboratory, University of Cambridge); Dr. R. J. Pumphrey, to investigate the sensory physiology of insects, and the electrical response in the central nervous system to peripheral stimulation of afferent nerves (Zoological Laboratory, University of Cambridge); T. A. H. Munro, to study the role of inheritance in mental disorder (Research Department, Royal Eastern Counties Institution, Colchester).

\section{Awards OF ROYal COMMISSION FOR THE ExHIBITION OF I85I}

The Science Scholarships Committee of the Royal Commission for the Exhibition of 1851 announces the following appointments for 1936 : Senior Studentships : Dr. R.C.L. Bosworth, for research in chemical physies at Cambridge; N. A. Burges, for research in mycology at Cambridge and the Strangeways Research Laboratory, Cambridge; T. T. Paterson, for research in geology and prehistory at Cambridge; A. F. Rawdon-Smith, for research in physiology and psychology at Cambridge; Dr. D. Shoenberg, for research in physics at Cambridge. All the above awards were made on the recommendation of the University of Cambridge. Overseas Scholarships : D. G. Hurst, for research in physics at the Universities of California and Cambridge; J. Marsden, for research in physical chemistry at the University of Cambridge; on the recommendation of McGill University, Montreal. A. D. Misener, for research in physies at the University of Oxford or Cambridge; S. L. Cohen, for research in biochemistry at the
Technische Hochschule, Zurich ; on the recommendation of the University of Toronto. H. C. Corben, for research in theoretical physics at the University of Cambridge; on the recommendation of the University of Melbourne. R. N. Robertson, for research in botany at the University of Cambridge; on the recommendation of the University of Sydney. I. E. Coop, for research in physical chemistry at the University of Oxford; on the recommendation of the University of New Zealand. Dr. B. G. Shapiro, for research in biochemistry at King's College Hospital, London; on the recommendation of the University of Cape Town. C. O'Kelly, for research in experimental physies at the University of Cambridge; on the recommendation of the National University of Ireland.

\section{Salters' Institute Awards}

The following awards for 1936-37 have been made by the Salters' Institute of Industrial Chemistry and approved by the Court of the Salters' Company : Fellowships renewed to : E. I. Akeroyd, Emmanuel College, Cambridge; L. R. Barrett, Lincoln College, Oxford; T. K. Hanson, Oriel College, Oxford ; and C. S. Windebank, University of London. Fellowships awarded to : L. M. Baxt, King's College, London; and T. A. Dent, St. Catharine's College, Cambridge. The Institute has also awarded 150 grants-in-aid to young men and women employed in chemical works to facilitate their further studies.

\section{Medical Research Council Awards}

The Medical Research Council announces the following awards of travelling fellowships for the academic year 1936-37 : Medical Research Council fellowships in medical science: J. T. Chesterman, H. E. Holling. Dorothy Temple Cross Research fellowships in tuberculosis : A. L. Jacobs, J. Smart, Dr. B. C. Thompson, V. C. Thompson. Rockefeller fellowship in psychiatry: Dr. J. H. Quastel.

\section{Excavations at Tell Duweir, Palestine, 1935-36}

\begin{abstract}
A $\mathrm{N}$ exhibition of antiquities from Tell Duweir, the ancient Lachish, which have been obtained by the fourth expedition of the Wellcome Archæological Research Expedition to the Near East in 1935-36, opened at the Wellcome Research Institute, Euston Road, London, N.W.I, on July 9 and will remain open until the end of the month.

The excavations, which again were under the field direction of Mr. J. L. Starkey, were mainly directed to completing the clearance of a number of areas attacked in the course of previous seasons' work; but nevertheless, material of considerable archæological interest and importance was obtained. An interesting group of bronze objects, much crushed, came from a quarry on the saddle, which had partially collapsed in ancient times. These objects date from the early Middle Bronze Age of pre-Hyksos times, and among them were a kohl stick and mirror, of which the latter is the first example to be found at Tell Duweir.
\end{abstract}

A further elearance of the temple and its super- imposed reconstructions made it elear that the essential plan of all three structures was identical, but that there had been a great expansion in the second temple. Further evidence was obtained pointing to the temple having been the seat of the cult of a triad of deities, of which one was female, and of affinities with the north. Below the floor of the second temple, a mass of pottery was found under the altar bench, which included a Late Helladic II goblet, dating at about 1450-1400 в.б. It is of buff paste with cream slip and has a painted band decoration showing an ivy leaf motif. This, from the point of view of the archæologist, is one of the most important finds of the season, as it dates more or less accurately, and links up a number of Palestinian finds.

Two sides, measuring eighty-five and seventy-five feet respectively, of a remarkable opening, apparently the entrance to a subterranean tunnel, have been cleared; and a clearance within the gate has revealed under the Persian level what was apparently the 